\title{
DEKATNYA KEDATANGAN KRISTUS YANG KEDUA ${ }^{\mathbf{1}}$
}

Berdasarkan Pernyataan Yesus Dalam Matius 10:23, Markus 9:1, dan 13:30

\author{
Adi Putra
}

\section{A. Pendahuluan}

Iman orang Kristen adalah iman yang meliputi waktu lampau, waktu sekarang dan waktu yang akan datang ${ }^{2}$. Yang dimaksud waktu lampau di sini adalah merujuk kepada kedatangan Kristus yang pertama - di mana kematian dan kebangkitan Kristus sebagai klimaksnya. Waktu sekarang merujuk kepada kehidupan aktual orang Kristen dalam mengekspresikan totalitas dirinya sebagai kristus-kristus kecil. Sedangkan waktu yang akan datang merujuk kepada kedatangan Kristus yang kedua - saat-saat yang senantiasa dinantikan, diyakini dan diinginkan oleh setiap orang Kristen. Anthony A. Hoekema mengatakan, "Kita sekarang ini hidup di antara kedua kedatangan tersebut. Kita melihat ke belakang dengan sukacita atas kedatangan Kristus yang pertama dan melihat ke depan dengan penuh harapan atas janji kedatangan-Nya kembali" (Hoekema 2004, 147).

Apabila membaca Alkitab, khususnya Perjanjian Baru pengharapan terhadap kedatangan Kristus yang kedua merupakan aspek yang paling ditekankan dalam eskatologi Perjanjian Baru. Tidak hanya kitab-kitab Injil yang menegaskan hal tersebut. Penekanan ini juga muncul secara dominan dalam Surat-surat Paulus, bahkan muncul dalam Surat-surat Umum. Seperti dalam Matius 16:27; Markus 14:62; Matius 24:42, 44; Lukas 12:37, 40, 43; 21:28; Yohanes 14:3; Kisah Para Rasul 1:11; 17:31; 1Tesalonika 5:2; Filipi 4:5; 1Korintus 4:5; Titus 2:13; Roma 8:19; Ibrani 9:28; Yakobus 5:8; 1Petrus 5:4; 2Petrus 3:10; 1Yohanes 2:28; 1Yohanes $3: 2$; Wahyu $1: 7 ; 3: 11 ; 22: 20$, dan sebagainya.

Berdasarkan apa yang dikemukakan oleh ayat-ayat Alkitab di atas, maka menjadi sebuah kewajaran apabila orang Kristen memiliki pengharapan yang sangat kuat terhadap kedatangan Kristus yang kedua. Justru apabila ada seseorang yang mengaku sebagai orang Kristen tetapi ternyata tidak memiliki pengharapan seperti di atas, maka pastilah ada yang salah pada diri orang tersebut. Dan bisa saja disebabkan oleh beberapa faktor. Seperti yang dikemukakan oleh Hoekema, "Memang barangkali ada banyak alasan yang menyebabkan

${ }^{1}$ Topik ini merupakan topik yang berada dalam lingkup eskatologi. Seperti yang dikatakan oleh Charles C. Ryrie, "Studi tentang akhir zaman (hal-hal yang masih bersifat akan datang dari pandangan kita) meliputi pengajaran alkitabiah mengenai keberadaan sesudah kematian tetapi sebelum dibangkitkan, kebangkitan, pengangkatan gereja, kedatangan Kristus kedua kali dan Kerajaan Seribu Tahun" (Ryrie 1986, 247-8). Memang makalah ini dibuat dalam kelas Eskatologi. Dan seperti yang dikemukakan oleh Ryrie di atas, maka apa yang dideskripsikan dalam makalah ini dibuat dalam bingkai Alkitab - lebih bersifat alkitabiah. Apa pentingnya mempelajari pokok-pokok eskatologi, seperti pokok "dekatnya kedatangan kembali"? Dalam bukunya, Ryrie juga memberikan beberapa poin tentang pentingnya orang Kristen memiliki pengetahuan eskatologi alkitabiah, yakni: (1) Supaya tetap memiliki sukacita di tengah-tengah penderitaan (2Kor. 4:17); (2) Supaya memiliki motivasi yang besar untuk hidup suci (1Yoh. 3:3); Sebagai suatu manfaat dalam praktik hidup sehari-hari (2Tim. 3:16-17); (4) Supaya memiliki pengetahuan mengenai fakta-fakta sesudah kematian (2Kor. 5:8); (5) Kebenaran tentang akhir sejarah; (6) Suatu pembuktian bahwa Alkitab tidak salah karena sebagian nubuatan sudah digenapi tengan tepat, bukan oleh karena kebetulan tetapi karena memang sudah direncanakan Allah; dan (7) Keinginan mendekatkan diri kepada Tuhan, lebih serius lagi dalam penyembahan kita kepada Allah yang mengontrol secara penuh dan yang menyelesaikan kehendak-Nya dalam sejarah. Meremehkan nubuatan berarti kehilangan keuntungan-keuntungan di atasnya (Ryrie 1986, 249).

${ }^{2}$ Pernyataan di atas senada dengan pendapat James Montgomery Boice yang mengatakan, “Allah, yang bertindak dalam sejarah dalam peristiwa-peristiwa masa lalu, juga bertindak di dalam sejarah untuk menggenapkan masa ini. Maka ketika kita bertanya, 'Bagaimana semua ini akan berakhir?' kita bukan tiba-tiba keluar dari realm sejarah dan masuk ke dalam spekulasi utopis di negeri antah berantah. Kita hanya melihat apa yang belum terjadi tetapi yang bagaimana pun pasti akan terjadi karena alasan yang sederhana: Allah dibaliknya dan Ia sendirilah yang mengatakan kepada kita bahwa itu akan terjadi" (Boice 2011, 814). 
kita kehilangan pengharapan eskatologis, misalnya karena kebanyakan gereja sekarang terjebak di dalam hal-hal materi dan sekuler sehingga minat terhadap Kedatangan Kedua memudar. Bisa pula karena banyak orang Kristen yang sudah tidak lagi mempercayai kedatangan Kristus kembali secara harfiah... Apa pun alasannya, hilangnya kesadaran tentang dekatnya kedatangan Kristus yang kedua merupakan tanda kemunduran rohani yang sangat serius" (Hoekema 2004, 149). Artinya, pokok kedatangan Kristus yang kedua merupakan pokok yang penting dalam kekristenan. Oleh karena orang Kristen yang tidak memiliki (mengakui) pengharapan ini adalah orang yang sedang mengalami permasalahan serius pada kehidupan rohaninya.

Dalam kalangan orang Kristen pun terdapat argumen yang variatif untuk pernyataan: kapan kedatangan Kristus yang kedua itu akan terjadi? Terlebih lagi apabila pertanyaan ini dikaitkan dengan teks dalam Matius 10:23, Markus 9:1, dan 13:303. Oleh karena cukup beragam interpretasi terhadap teks-teks ini - bahkan tidak sedikit yang akhirnya memberikan kesimpulan yang mendiskreditkan Yesus sebagai sosok sentral dari pokok ini.

Tulisannya yang berjudul The Quest of the Historical Jesus, Albert Schweitzer memunculkan istilah penundaan parousia yang berbunyi, Yesus sendiri mengharapkan kedatangan-Nya yang kedua (parousia) akan segera terjadi dan Kerajaan-Nya segera tiba sebelum para murid selesai mengabarkan Injil ke seluruh kota-kota Israel. Ketika mereka kembali, ternyata peristiwa itu tidak terjadi, maka Yesus mulai sadar bahwa Dia telah salah dalam memprediksi kedatangan kedua-Nya, hal inilah yang kemudian disebut dengan penundaan kedatangan kedua (Hoekema 2004, 150).

Oscar Cullmann yang juga merupakan teolog modern yang meyakini akan adanya kedatangan Kristus yang kedua. Akan tetapi baginya, anggapan jemaat mula-mula tentang kedatangan Kristus kembali yang akan segera terjadi adalah sebuah kesalahan perspektif. Hal senada pun juga dikemukakan oleh Werner G. Kummel. Baginya, dalam hal ini Yesus telah melakukan kesalahan, karena Yesus bukan hanya memproklamasikan kedatangan Kerajaan Allah dengan menggunakan keterangan waktu sudah sangat dekat. Sehingga seolah-olah peristiwa itu akan terjadi dalam kurun waktu para pendengar yang mendengar perkataan-Nya itu. Sehingga ketika peristiwa itu tidak terjadi maka dapat disimpulkan bahwa Yesus telah keliru memprediksi kedatangan-Nya yang kedua (Hoekema 2004, 151).

Bahkan menurut Sinclair B. Ferguson dkk., "Dunia kesarjanaan abad XX telah menaruh kepedulian besar dengan masalah penundaan parousia: karena pengharapan gereja mulamula pada kedatangan yang segera tidak terpenuhi.." (Ferguson 2009, 63). Hal ini mengindikasikan bahwa mayoritas teolog zaman modern bahkan post-modern tidak lagi yakin akan adanya peristiwa parousia, oleh karena sejak gereja mula-mula peristiwa itu tidak juga terjadi.

Kekeliruan-kekeliruan inilah yang coba untuk diluruskan dan diberikan klarifikasi melalui tulisan ini. Akan tetapi, sebelumnya akan dideskripsikan beberapa pandangan yang keliru kemudian mengidentifikasinya guna dapat memberikan klarifikasi yang tepat.

\section{B. Beberapa Pandangan Terhadap Pernyataan Yesus dalam Injil}

Matius 10:23. Ayat ini berbunyi: "Apabila mereka menganiaya kamu dalam kota yang satu, larilah ke kota yang lain; karena Aku berkata kepadamu: Sesungguhnya sebelum kamu selesai mengunjungi kota-kota Israel, Anak Manusia sudah datang" (Terjemahan Baru LAI). Berikut ini akan dikemukakan beberapa pendapat terhadap ayat di atas, yakni:

\footnotetext{
${ }^{3}$ Meskipun sebenarnya dalam Perjanjian Baru, satu dari dua puluh lima ayat membahas kembalinya Tuhan. Kembalinya Tuhan disebutkan 318 kali dalam 260 pasal. Topik ini juga mewakili tempat yang penting dalam Perjanjian Lama, di mana kebanyakan nubuat-nubuat Perjanjian Lama yang membahas kedatangan Kristus bukan berbicara tentang kedatangan-Nya yang pertama di mana Ia mati sebagai pemikul dosa, tetapi tentang kedatangan-Nya yang kedua di mana Ia harus memerintah sebagai Raja (band. Boice 2011, 816).
} 
1. Penafsiran Albert Schweitzer, Fritz Buri, dan Martin Werner (eskatologi yang konsisten) menganggap bahwa apa yang dikemukakan oleh Yesus di sini adalah sebuah delusi (Yesus sedang berdelusi). Bagi mereka, Yesus bukan hanya salah dalam memprediksi waktu kedatangan-Nya tetapi juga keseluruhan konteks eskatologi di mana Ia menempatkan Kerajaan-Nya - sebenarnya tidak ada parousia dan kerajaan yang akan datang. Menurut Werner, konsep kedatangan kedua lebih banyak dipengaruhi pemahaman apokaliptik Yahudi dan tidak sesuai dengan iman Kristen sehingga harus ditolak (Hoekema 2004, 150, 159).

2. Pandangan Plumer, Kummel, dan Cullmann yang berpendapat bahwa frasa "sebelum kamu selesai mengunjungi kota-kota Israel" merujuk kepada pemberitaan Injil yang dilakukan oleh kedua belas murid Tuhan Yesus di kota-kota Israel dalam kurun waktu yang lebih panjang dari yang dikemukakan oleh Matius 10. Sedangkan frasa "Anak Manusia sudah datang" merujuk kepada second coming. Akan tetapi hal itu ternyata tidak terjadi maka mereka akhirnya menyimpulkan bahwa kesalahan terjadi pada pihak Matius (Plummer), bahkan bisa juga terletak pada Yesus sendiri (Cullmann, Kummel) (band. Hoekema 2004, 159, §1).

3. Pandangan Tasker, Calvin ${ }^{4}$, dan Lenski juga setuju dengan pandangan sebelumnya tentang "mengunjungi kota-kota Israel" merujuk kepada pemberitaan Injil yang dilakukan oleh kedua belas murid kepada orang Yahudi sepanjang hidup mereka. Sedangkan untuk frasa "Anak Manusia sudah datang" bagi kelompok ini tidak merujuk kepada kedatangan Kristus yang kedua, melainkan kepada peristiwa-peristiwa yang terjadi tidak lama dari saat Yesus mengucapkan perkataan ini. Bisa saja merujuk kepada penampakan Kristus yang telah bangkit dan pemberian Amanat Agung kepada para murid (Tasker). Atau kepada penyebaran Injil yang mewujudkan pemerintahan Kristus di atas bumi (Calvin), serta kepada keruntuhan Yerusalem (Lenski) (band. Hoekema 2004, 159, §2).

4. Pandangan Ridderbos, Grosheide, Schniewind dan Ladd yang sepakat bahwa frasa "Anak Manusia sudah datang" merujuk kepada kedatangan Kristus di awan-awan. Sedangkan frasa "mengunjungi kota-kota Israel" harus diartikan secara figuratif, di mana menggambarkan aktivitas yang akan terus berlangsung hingga Kedatangan Kedua. Meskipun demikian, dalam penjelasan detailnya, mereka berbeda. Ridderbos berpendapat frasa "mengunjungi kota-kota Israel" dipakai oleh Yesus untuk menubuatkan muridmurid yang memberitakan Injil tetapi selamanya akan mengalami penganiayaan hingga akhir zaman - namun selalu ada tempat bagi mereka untuk melarikan diri. Grosheide melihat ayat ini hendak menyatakan bahwa gereja harus terus memberitakan Injil hingga kedatangan Kristus yang kedua. Sedangkan frasa "kota-kota Israel" merujuk kepada tempat-tempat di mana terdapat orang-orang yang mengaku Kristus - namun sebenarnya jauh dari Allah. Bagi Ladd dan Schniewind, frasa "mengunjungi kota-kota Israel" merupakan gambaran misi gereja terhadap bangsa Israel yang akan terus berlangsung hingga kedatangan Kristus yang kedua, dan yang akan menghasilkan keselamatan bagi banyak orang Yahudi (Hoekema 2004, 159-60). Intinya, bagi Grosheide, Schniewind dan Ladd, perkataan Yesus di sini lebih cocok apabila dipahami dalam kerangka misiologi.

Setelah memperhatikan, menyimak dan menganalisis pendapat-pendapat di atas, maka dengan jelas dapat dilihat adanya pendapat yang variatif. Ada yang mengatakan bahwa di sini terjadi kekeliruan (bisa saja dari Matius maupun dari Yesus). Ada pendapat yang sama sekali tidak mengaitkan ayat ini dengan kedatangan yang kedua - sebaliknya lebih kepada

${ }^{4}$ Blomberg juga memberikan penjelasan tambahan tentang pendapat Calvin terhadap ayat ini. Bagi Calvin, "It is fulfilled in Pentecost and the coming of the Spirit (Osborne 2010, 391). 
peristiwa-peristiwa yang terjadi tidak lama setelah Yesus mengemukakan pernyataan ini. Ada juga yang melihat ayat ini lebih kepada aspek misiologi.

Markus 9:1. Perikop ini berbunyi, "Kata-Nya kepada mereka: 'Aku berkata kepadamu, sesungguhnya di antara orang yang hadir di sini ada yang tidak akan mati sebelum mereka melihat bahwa Kerajaan Allah telah datang dengan kuasa". Berikut ini akan dikemukakan beberapa pandangan terhadap ayat ini:

1. Kummel dan Cullmann berpendapat bahwa di sini Yesus sedang menubuatkan kedatangan-Nya kembali yang akan segera terjadi pada masa itu juga - yaitu ketika para pendengar saat itu masih hidup (Hoekema 2004, 153).

2. Menurut Plummer, Cranfield, H. Berkhof, Lane berpendapat bahwa sebenarnya Yesus sedang berbicara tentang peristiwa transfigurasi, sebuah kejadian yang dicatat dalam ketiga Injil Sinoptik - sebagai peristiwa yang mengikuti kalimat Yesus tersebut (Hoekema 2004, 153).

3. Calvin, Grosheide, Tasker, Hendriksen mengemukakan bahwa Yesus sedang menubuatkan kebangkitan-Nya, dan pencurahan Roh Kudus yang mengikutinya. Kelompok ini mengaitkan perikop ini dengan Roma 1:4 (Hoekema 2004, 153).

4. J.A.C. van Leeuwen mengemukakan bahwa Yesus sedang berbicara tentang penyataan Kerajaan Allah pada hari Pentakosta, penghakiman-Nya atas Yerusalem, atau penyebarluasan berita Injil ke seluruh dunia (Hoekema 2004, 153).

5. Lenski dan Greijdanus menegaskan bahwa Yesus sedang berbicara tentang penghancuran Yerusalem dan orang-orang Yahudi yang akan lari dari kota itu, yang dengan demikian mempersiapkan mempersiapkan jalan bagi pembentukan Israel baru yang terdiri dari orang-orang Yahudi dan non-Yahudi.

Mayoritas pendapat dari teolog atau pun penafsir di atas menegaskan bahwa teks dari Markus 9:1 tidak berbicara tentang kedatangan Kristus yang kedua. Hanya Kummel dan Cullmann yang setuju bahwa perikop ini merujuk kepada kedatangan Kristus yang Kedua meskipun salah di dalam memahami kapan peristiwa itu akan terjadi. Semua teolog dan penafsir di atas sepakat bahwa teks Markus 9:1 adalah merujuk kepada peristiwa yang akan terjadi tidak lama setelah Yesus mengucapkan pernyataan tersebut. Sehingga indikasi bahwa orang-orang yang mendengarkan perkataan Yesus itu pasti juga akan menyaksikan peristiwaperistiwa yang ada dalam nubuatan tersebut.

Markus 13:30. Dalam ayat ini tertulis, "Aku berkata kepadamu: Sesungguhnya angkatan ini tidak akan berlalu, sebelum semuanya itu terjadi". Berikut ini akan dikemukakan beberapa pendapat dari para teolog atau para penafsir terhadap ayat ini.

1. Cullmann dan Kummel berpendapat, frasa "angkatan ini" merujuk kepada generasi orang-orang yang mendengar perkataan Yesus saat itu. Sehingga untuk frasa "sebelum semuanya itu terjadi" dalam ayat ini merujuk kepada segala peristiwa yang akan segera diikuti oleh parousia. Akan tetapi ketika parousia itu tidak terjadi, maka kelompok ini berpendapat bahwa telah terjadi kesalahan perspektif atau perhitungan pada diri Yesus. Jadi, kelompok ini memahami pernyataan Yesus dalam ayat ini sebagai usaha yang Yesus lakukan untuk menetapkan sebuah waktu yang pasti bagi kedatangan-Nya yang kedua (Hoekema 2004, 155-6).

2. Calvin, Plummer, Geldenhuys, Cole, Lane tidak sama dengan kelompok sebelumnya, dengan mengatakan bahwa frasa "angkatan ini" dipahami dalam pengertian kualitatif dan bukan soal waktu, artinya kata-kata ini menggambarkan baik orang Yahudi maupun orang-orang yang tidak percaya yang hidup sejak zaman Yesus hingga kedatangan-Nya yang kedua. Dan bagi kelompok ini, kata "semuanya" dipahami sebagai nubuat bagi 
penghancuran Yerusalem dan kesengsaraan yang diakibatkan oleh penghancuran tersebut - jadi ayat ini menggambarkan peristiwa pada akhir zaman (Hoekema 2004, 156).

3. Theodor Zahn, Cranfield, Ladd setuju dengan pandangan Cullmann dan Kummel dalam memahami frasa "angkatan ini". Akan tetapi untuk frasa "sebelum semuanya itu terjadi" mereka pahami sebagai tanda-tanda akhir zaman sebagaimana digambarkan dalam Markus 13:5-23. Jadi tanda-tanda itu akan mendahului kedatangan Kristus kembali, tetapi mereka tidak akan menyaksikan kedatangan itu sendiri (Hoekema 2004, 156).

4. Pandangan terakhir untuk teks dalam Markus 13:30 adalah dengan menafsirkan frasa "angkatan ini" dalam pengertian kualitatif dan bukan soal waktu. Tokoh-tokoh yang mendukung pendapat ini seperti Grosheide, Schniewind, Hendriksen, van Leeuwen dan Lenski. Meskipun dalam penekanannya mereka berbeda. Misalnya, Grosheide yang berpendapat bahwa "angkatan ini" memiliki makna umat manusia secara umum, sehingga dikatakan bahwa mereka akan tetap ada sampai parousia. Schniewind dan Hendriksen sedikit berbeda dengan mengatakan, frasa "angkatan ini" sebagai petunjuk bahwa orangorang Yahudi akan tetap ada hingga akhir zaman; sehingga melalui perkataan Yesus ini mengindikasikan bahwa aka nada pengharapan keselamatan bagi orang-orang Yahudi hingga akhir zaman. Kemudian van Leeuwen menambahkannya bahwa mereka bukannya akan memperoleh keselamatan, melainkan justru akan memberontak dan menolak sang Mesias;... dan "sebelum semuanya itu terjadi" dipahami sebagai tanda-tanda yang akan mendahului parousia tetapi tidak termasuk parousia itu sendiri. Akan tetapi bagi Lenski, "semuanya" di sini berarti mencakup parousia itu sendiri (Hoekema 2004, 156-7).

Dari pendapat-pendapat di atas memang mayoritas memahami ayat ini merujuk kepada parousia atau kedatangan Kristus yang kedua. Meskipun kapan parousia itu akan terjadi, ternyata juga tidak jelas dalam pendapat-pendapat mereka. Memang yang harus diperhatikan pada perikop ini adalah frasa "angkatan ini" dan "sebelum semuanya ini terjadi". Apakah maksudnya? Para teolog dan penafsir di atas memiliki pendapat yang bervariasi. Akan tetapi tidak perlu terburu-buru untuk mengklaim pendapat mana yang paling tepat.

\section{Interpretasi Terhadap Pernyataan Yesus dalam Injil}

Apa sebenarnya yang hendak disampaikan oleh teks dalam perikop-perikop di atas? Apakah teks-teks itu memang berbicara tentang kedatangan Kristus yang kedua? Hal inilah yang akan dijelaskan dalam bagian ini.

Matius 10:23. Dalam tafsirannya, Osborne setuju dengan pendapat Gnilka, Davies, Allison, Blomberg, Wilkins dan Turner, yang mengatakan, "Jesus expected a lengthy period before the end $(13: 24-33 ; 18: 15-18 ; 19: 28 ; 21: 43 ; 23: 32 ; 28: 19)$ and so is saying that mission to Israel is ongoing and will not conclude until the parousia" (Osborne 2010, 391). Jadi, baginya perkataan ini merujuk kepada periode yang panjang sebelum akhir zaman yang berbicara tentang misi kepada bangsa bangsa Israel terus berlangsung dan tidak akan berhenti hingga kepada kedatangan Kristus yang kedua. R.T. France mengomentari ayat ini dengan menjelaskan, "The towns of Israel is a geographical expression and can hardly mean 'all Jewish communities (including the Diaspora); in this context of the Galilean mission it apparently means Palestine. But it is not clear what it means to 'complete' these towns: suggestions include the preaching of the Gospel in each town, the convertion of 'all Israel' (as in Rm. 11:26), or the exhausting of possible places of refuge from persecution...The Son of Man comes is an echo of the language of Daniel 7:13, which does not speak of the 'son of man' coming to earth, but rather coming to God to receive authority, and Jesus' frequent uses of such language show that he applied it to his own future glory in times and situations varying from his vindication after the resurrection (26:64 cf. 28:18, echoing Dn. 7:14) to the 
final judgment (25:31; cf. 19:28)" (France 2007, 184). Jadi France mengatakan bahwa memang frasa 'kota-kota Israel', dalam konteks misi Galilea rupanya berarti misi Palestina. Tetapi ini tidak tuntas dalam makna keseluruhan dari kota-kota ini. Ada beberapa saran seperti: memberitakan Injil di setiap kota, pertobatan dari semua orang Israel (seperti dalam Rm. 11:26), atau kesusahan dari kemungkinan kota-kota tempat perlindungan dari penyiksaan. Dan untuk frasa 'Anak Manusia sudah datang' menurutnya bahwa ketika Yesus mengucapkan frasa ini adalah untuk menunjuk kemuliaan-Nya sendiri dalam waktu dan situasi yang bervariasi dari mempertahankan nama baik-Nya setelah kebangkitan kepada penghakiman terakhir. Hal ini disebabkan karena gema yang juga berasal dari Daniel 7:13 ini lebih tepat kepada kedatangan Allah untuk menerima otoritas. Dalam hal ini dipahami merujuk kepada situasi Yesus setelah kebangkitan hingga penghakiman terakhir.

Bagi Donald A. Hagner, "You will not at all complete the cities of Israel, refers either to exhausting the cities that can be used for refuge from persecution of the task of evangelizing. In short, the mission to Israel - the specific mission referred to in v. 6 and not an open-ended mission to the Jews in the indeterminate future - will not be concluded before 'the Son of Man comes'...The classical meaning of the coming of the Son of Man, as, for example, found in 16:27-28; and 24:30, relies on Dan. 7:13-14 and refers to the end of the present age and the parousia or second coming of Jesus" (Hagner 1993, 279). Bagi Hagner, frasa "mengunjungi kota-kota Israel" merujuk juga kepada kesusahan kota-kota itu dapat digunakan untuk tempat perlindungan dari tugas memberitakan Injil. Misi kepada bangsa Israel menunjuk kepada ayat 6 dan bukan awal berakhirnya misi kepada orang Yahudi dalam waktu tak ditentukan di masa depan - tidak akan diakhiri sebelum Anak Manusia datang. Sedangkan untuk frasa 'Anak Manusia' menurutnya, maknanya ditemukan juga dalam 16:2728; 24:30 berdasarkan Daniel 7:13-14 dan menunjuk kepada akhir zaman dan parousia atau kedatangan kedua Kristus.

Jadi, berdasarkan beberapa tafsiran dari para teolog di atas, maka semuanya hampir setuju bahwa frasa "Anak Manusia sudah datang" harus dipahami sebagai kedatangan Kristus yang kedua. Dan sebelum sampai kepada peristiwa itu, akan didahului dengan tanda-tanda seperti yang dijelaskan dalam ayat ini: para murid bahkan seluruh orang Kristen di sepanjang abad akan pergi memberitakan Injil - untuk tugas ini mereka akan dianiaya. Dan bagi Hoekema, aktivitas yang digambarkan dalam ayat ini akan terjadi setelah kenaikan Yesus ke Surga bahkan dapat diaplikasikan kepada orang Kristen di sepanjang sejarah. Oleh karena ketika Yesus berbicara kepada murid-murid-Nya, Dia seringkali menggabungkan hal-hal yang akan segera terjadi dengan peristiwa-peristiwa yang masih jauh di depan - sebuah prinsip nubuat para nabi dalam Perjanjian Lama (Hoekema 2004, 160).

Selain itu, hal penting yang juga diperoleh setelah menyimak tafsiran di atas bahwa bangsa Israel masih senantiasa menjadi objek pemberitaan Injil hingga akhir zaman/kedatangan kedua Kristus. Akan tetapi tidak menutup kemungkinan untuk mereka senantiasa menolak Injil itu - sehingga konsekuensinya adalah kedatangan kedua Kristus bukan sebagai keselamatan melainkan sebagai penghakiman bagi mereka. Meskipun juga penolakan terhadap Injil tidak hanya berasal dari orang-orang Yahudi saja. Oleh karena objek dari pemberitaan para murid serta seluruh Gereja di sepanjang sejarah adalah seluruh dunia.

Markus 9:1. Dalam ayat ini, sebenarnya hal yang harus mendapat perhatian utama, yakni: orang yang hadir di sini ada yang tidak akan mati sebelum mereka melihat bahwa Kerajaan Allah telah datang dengan kuasa. Bagi Jacob van Bruggen, "Merasakan atau mengalami kematian memiliki makna bahwa beberapa orang tidak akan mengalami rasa maut sampai mereka melihat kedatangan Kerajaan Allah. Pada waktu kedatangan-Nya, karena kuasa yang mengiringi kedatangan itu, maut sendiri pun akan disingkirkan" (van Bruggen 2006, 296). Apabila menyimak apa yang dikemukakan oleh van Bruggen di atas, maka baginya frasa ini 
sebenarnya hendak menegaskan bahwa 'beberapa orang yang hadir di situ sudah akan dibebaskan dari kuasa maut, walaupun secara sempurna hal itu akan dialami pada waktu kedatangan-Nya kelak. Jadi tetapi ayat ini juga menunjuk kepada parousia atau kedatangan kedua Kristus.

Bagi R. Alan Cole, "The verse must, therefore, refer either to the transfiguration which follows immediately after, which seems reasonable; or to the coming of the Spirit; or to later events, still within a human lifespan, such as Christ's triumph on the cross, confirmed by the resurrection (Col. 2:15); or to the coming Spirit; or to the later extention of the blessings of the kingdom to the Gentiles as outlined in the book of Acts. Of these, perharps the combined event of cross and resurrection is the best interpretation, if we reject the transfiguration as the meaning" (Cole 2007, 209). Bagi Cole, ayat ini mengacu kepada peristiwa transfigurasi, karena peristiwa ini yang segera mengikutinya; atau peristiwa kedatangan Roh Kudus atau peristiwa berikutnya. Akan tetapi apabila peristiwa transfigurasi ditolak, maka mengkombinasikan peristiwa penyaliban sampai kepada kebangkitan adalah yang terbaik.

Dari dua tafsiran di atas, memperlihatkan adanya dua penekanan waktu, yakni menunjuk kepada masa depan atau parousia atau kedatangan kedua Kristus; serta menunjuk juga kepada peristiwa yang segera terjadi, yakni: kepada kebangkitan-Nya. Sebenarnya van Bruggen mengakui kedua aspek waktu ini - meskipun dalam penekanannya aspek parousia lebih ditonjolkan. Konsep ini senada dengan pendapat Ridderbos dalam bukunya yang berjudul Coming of Kingdom mengatakan, adanya dua perspektif dalam nubuat Yesus tentang apa yang akan terjadi pada akhir zaman. Perspektif yang pertama ialah yang menunjuk kepada kematian-Nya yang akan segera terjadi dan yang akan diikuti oleh kebangkitan-Nya. Perspektif yang kedua menunjuk kepada kedatangan-Nya yang kedua di dalam kemuliaan (Hoekema 2004, 154).

Dengan demikian, ayat ini harus dipahami tidak boleh terlepas dari pengharapan akan peristiwa kedatangan kedua Kristus. Tentu sebelum sampai kepada peristiwa itu, maka perlu juga melewati satu peristiwa penting, yakni kebangkitan Kristus. Karena melalui peristiwa inilah Anak Manusia dimuliakan dan datang dalam kuasa. Mengapa kedua peristiwa ini tidak dapat dipisahkan? Oleh karena dalam paradigma murid-murid waktu itu, kebangkitan dan kedatangan Kristus pada waktu itu tidak dapat dipisahkan. Selain itu, kebangkitan Kristus juga dapat dikatakan sebagai jaminan akan terealisasinya peristiwa kedatangan yang kedua.

Markus 13:30. Menurut F. F. Bruce, ada dua hal yang menjadi penting guna bisa memahami ayat ini dengan baik. Kedua hal itu adalah 'semuanya itu' dan 'angkatan ini'. Baginya, untuk bias mengerti frasa 'semuanya itu' bergantung kepada siapa yang dimaksud dengan 'angkatan ini'. Ungkapan 'angkatan ini' sering muncul dalam Alkitab. Dan tiap kali ungkapan ini dipakai untuk menunjuk kepada sekelompok manusia tertentu. Sambil tetap berpegang bahwa Tuhan Yesus tidak mungkin keliru dalam nubuat-Nya, kita tidak mengartikan 'angkatan ini' sebagai 'angkatan yang sekarang hidup', tetapi 'angkatan yang akan hidup'. Sehingga frasa ini harus dipahami: 'Angkatan yang ada di bumi saat semuanya ini terjadi akan tetap berada di bumi sampai semuanya berakhir: semuanya itu terjadi dalam kurun waktu satu generasi... Sedangkan 'semuanya itu' menunjuk kepada penghancuran Bait Allah di Yerusalem - hal ini didasarkan pada konteks ayat ini. Jadi, perkataan Yesus ini sebenarnya bermakna, 'Angkatan ini tidak akan berlalu sebelum Bait Allah diruntuhkan'. (Bruce 2011, 253-4). Berdasarkan uraian di atas, maka bagi Bruce peristiwa itu lebih cocok menunjuk kepada penghancuran Bait Allah dan seolah-olah masuk akal karena peluang untuk orang-orang yang hadir waktu itu dapat menyaksikan peristiwa tersebut terbuka lebar.

Sedangkan bagi Cole, "This generation must surely be the generation of Jesus' earthly ministry, some of whom would indeed have lived to see the awful days of the siege of Jerusalem. But the generation of the ministry would not of course see Christ's second 
coming, so some have striven, rather unnaturally, to interpret genea as meaning 'people', and refer it to the whole Jewish nation, which will not pass away before that time. Undoubtedly, the delay in the second coming of the Lord (the parousia) was a puzzle to the early church, many of whom seem to have expected it in their lifetime, and were therefore saddened and troubled when, one by one, death carried them away before it (2Ptr. 3:4). It is therefore better to restrict the reference in these things to the temporal judgment of $\mathrm{AD} 70$. But, in anticipating the Lord's return at any moment, the infant church was making no mistake, for every generation should continually be eagerly looking for and expecting the coming (2Ptr. $3: 12$ ). In the purpose of God, no event now stands between Christ's ascension and His second coming, and so it is eternally near" (Cole 2007, 282). Maksudnya, generasi ini harus dipahami generasi yang menyaksikan pelayanan Kristus di bumi, dan beberapa dari mereka memang melihat peristiwa mengerikan ketika Yerusalem dikepung. Akan tetapi, mereka tidak akan pernah menyaksikan kedatang kedua Kristus. Sehingga ada beberapa penafsir yang menafsirkan kata 'genea' dengan menunjuk kepada bangsa Yahudi secara keseluruhan yang tidak akan berlalu sebelum waktu itu (mungkin yang dimaksud kedatangan kedua Yesus). Meskipun bagi Cole, kedatangan kedua Kristus adalah sebuah teka-teki yang harus dijawab oleh Gereja mula-mula. Karena banyak di antara mereka yang memang sudah sangat berharap bahwa peristiwa itu akan terjadi dalam zaman mereka, akan tetapi sampai mereka mati ternyata peristiwa itu tetap tidak terjadi. Maka bagi Cole, untuk lebih baik memahami hal ini dalam konteks penghakiman temporal pada tahun 70 AD. Gereja mula-mula tetap tidak keliru, untuk setiap generasi harus terus akan bersemangat mencari dan mengharapkan kedatangan kedua Kristus - kedatangan kedua Kristus itu selalu dekat.

Bagi van Bruggen, angkatan ini berarti generasi abad pertama. Keyakinan ini didukung oleh dua hal, yaitu adanya pronominal penunjuk (haute / ini), dan tidak adanya kata sifat (hanya bersama kata sifat genea, yang diartikan jenis). Tetapi 'semuanya itu' tidak bias diartikan sebagai kesudahan dunia, karena dalam ayat 32 Yesus dengan tegas membedakan 'semuanya itu', yaitu peristiwa-peristiwa yang akan berlangsung pada masa satu generasi, dari 'hari dan saat' yang tidak diketahui oleh siapa pun, bahkan Anak pun tidak. Jadi, 'hari dan saat itu' tidak tercakup di dalam 'semuanya itu'. Dan bagi van Bruggen, di sini Yesus menubuatkan bahwa Bait Allah akan dihancurkan dan penganiayaan besar akan mulai berlangsung pada masa 'angkatan ini'. Dia menghimbau para murid supaya terus memandang semua peristiwa itu sebagai pra-tanda musim panas yang pasti akan datang, sebagai pra-tanda 'hari dan saat itu', yaitu hari dan saat kedatangan Anak Manusia yang kedua (van Bruggen 2006, 499-500).

Dari ketiga tafsiran di atas, dapat dilihat dengan jelas bahwa ketiga-tiganya sepakat bahwa frasa 'angkatan ini' merujuk kepada generasi pertama dari Gereja, yang tentu harus dipahami sebagai orang-orang yang menyaksikan Yesus melayani di bumi ini. Dan untuk frasa 'semuanya ini' harus dipahami sebagai penghancuran Bait Allah yang tidak lama terjadi setelah Yesus mengatakan perkataan ini, tepatnya pada tahun $70 \mathrm{AD}$. Lalu, apakah ayat ini berbicara tentang kedatangan kedua Kristus? Berdasarkan apa yang dikemukakan oleh penafsir-penafsir di atas, ayat ini secara gamblang berbicara tentang penghancuran Bait Allah - akan tetapi peristiwa ini ternyata juga memiliki hubungan dengan kedatangan yang kedua. Berdasarkan ayat 32, memang tidak mungkin dalam ayat 30 Yesus menubuatkan tentang kedatangan-Nya yang kedua. Seperti dalam tafsiran van Bruggen di atas, menegaskan bahwa justru peristiwa penghancuran Bait Allah menjadi momen yang menandakan bahwa kedatangan yang kedua Kristus benar-benar akan terjadi. Karena peristiwa itu merupakan titik awal dari rangkaian peristiwa kedatangan Kristus yang kedua, di mana setelah itu ditandai dengan penganiayaan terhadap gereja sebagai konsekuensi dari pemberitaan Injil sekaligus menjadi tanda-tanda akan kedatangan kedua Kristus. 
Ternyata Hoekema pun membenarkan konsep di atas dengan berkata, "Tujuan Yesus mengatakan kata-kata ini (13:30) bukanlah untuk memberitahukan saat atau hari tertentu bagi kedatangan-Nya kembali...Meskipun benar bahwa konteks Firman yang disampaikan oleh Yesus dalam Markus 13 adalah nubuat tentang keruntuhan Bait Allah (ay.2), namun firman itu mencakup nubuat tentang terjadinya peperangan atau kabar tentang peperangan (ay. 7), gempa bumi dan kelaparan (ay.8), pemberitaan Injil kepada semua bangsa (ay. 10), penganiayaan karena nama Kristus (ay.12-13), siksaan 'seperti yang belum pernah terjadi..dan tidak akan terjadi lagi' (ay. 19), tanda-tanda di langit (24), kedatangan Anak Manusia di awan-awan dengan segala kekuasaan dan kemuliaan-Nya (ay.26)... Karena itu, saya menyimpulkan bahwa 'semuanya' yang dimaksudkan oleh Yesus adalah semua peristiwa eskatologis yang telah Ia sebutkan, termasuk tentunya kedatangan-Nya di awanawan. Apa yang hendak Tuhan tegaskan ialah bahwa semua peristiwa ini pasti akan terjadi. Hal ini dijamin dengan kata-kata Yesus sendiri bahwa meskipun 'langit dan bumi akan berlalu, tetapi perkataan-Ku tidak akan berlalu'” (Hoekema 2004, 157).

Berdasarkan pemaparan interpretative terhadap tiga ayat di atas, maka disimpulkan bahwa maksud ketiganya memang menunjuk kepada parousia atau kedatangan kedua Kristus. Meskipun kepastian akan peristiwa parousia ini mulai terasa sejak kebangkitan-Nya, penghancuran Bait Allah, penganiayaan orang Kristen, dan pemberitaan Injil. Semua ini akan menjadi tanda-tanda yang mengawali peristiwa kedatangan Kristus.

Lalu, kapan parousia itu terjadi? Ayat ini tidak berbicara hal tersebut. Meskipun demikian, satu hal yang hendak ditegaskan oleh ayat-ayat ini adalah tentang kepastian dan sifat misteri dari parousia itu. Hal ini ditegaskan juga dalam Markus 13:32 yang berbunyi, "Tetapi tentang hari dan saat itu tidak seorang pun yang tahun, malaikat-malaikat di Surga tidak, dan Anak pun tidak, hanya Bapa saja" (Terjemahan LAI-TB). ${ }^{5}$

Bagi Berkhof, Matius 24:36 menjadi indikasi yang kuat bahwa tidak ada seorang pun yang kapan waktu yang tepat bagi kedatangan Kristus yang kedua, dan semua usaha dari manusia yang mencoba menjelaskan tanggal yang tepat pastilah keliru (Berkhof 1997, 85).

\section{Bagaimana Memahami Kedatangan Kristus yang Kedua?}

1. Kedatangan Kristus yang kedua harus dipahami sebagai sebuah peristiwa tunggal meskipun tidak bisa dilepaskan dari rangkaian peristiwa yang mengawalinya, seperti: kebangkitan-Nya, keruntuhan Bait Allah, penganiayaan orang Kristen, bencana alam, peperangan, munculnya Anti-Kristus, dan pemberitaan Injil kepada semua bangsa.

2. Berdasarkan Markus 13:32, Kedatangan Kristus merupakan sebuah misteri - hanya Bapa yang tahu. Bahkan berdasarkan teks tersebut, Yesus pun tidak tahu kapan peristiwa itu akan terjadi. Akan tetapi, berdasarkan pemaparan tafsiran terhadap tiga teks Firman Tuhan di atas (Mat. 10:23; Mrk. 9:1; 13:30), maka kedatangan kedua Kristus adalah peristiwa yang pasti terjadi dan akan segera terjadi.

3. Kedatangan Kristus untuk orang yang percaya kepada-Nya menjadi suatu sukacita yang besar, oleh karena peristiwa itu akan memberikan kegenapan akan janji dalam iman percaya-Nya. Sedangkan bagi orang yang tidak percaya, kedatangan kedua Kristus akan menjadi malapetaka yang besar. Oleh karena melalui peristiwa ini, mereka akan dihakimi dan akan memperoleh penghukuman yang kekal.

4. Cara kedatangan kedua Kristus harus dipahami sebagai kedatangan ini sebagai kedatangan yang personal; kedatangan ini adalah kedatangan yang bersifat jasmani;

${ }^{5}$ Ferguson dkk. Mengemukakan bahwa bagian-bagian ini (Mat. 10, Mrk. 9 dan 13) tidak bertujuan untuk memungkinkan perhitungan jadwal waktu eskatologis tetapi untuk memperingatkan tentang konflik yang akan terjadi sepanjang sejarah hingga parousia (Ferguson dkk. 2009, 63). 
kedatangan ini akan merupakan kedatangan yang bisa disaksikan; kedatangan itu akan sangat tiba-tiba (band. Berkhof 1997, 87-90).

\section{E. Kesimpulan}

Berdasarkan pemaparan makalah ini secara singkat dan jelas, maka dapat dikatakan bahwa kedatangan Kristus yang kedua "sudah sangat dekat". Meskipun demikian, bukan berarti kedatangan kedua Kristus akan terealisasi pada masa kehidupan orang-orang yang mendengarkan perkataan-Nya pada waktu itu.

Dengan demikian, orang Kristen masa kini melihat kepada ekspresi orang Kristen mulamula terhadap kepercayaan mereka kepada peristiwa kedatangan kedua Kristus secara pribadi, yang erat hubungannya dengan sebuah masa kefasikan yang dahsyat di bumi, kebangkitan dan transformasi tubuh mereka sendiri, kemuliaan Tuhan Yesus dan penghukuman-penghukuman kepada setiap orang fasik. Setidaknya berita ini menjadi sebuah berita pengharapan untuk kehidupan di tengah-tengah penderitaan karena percaya kepada Kristus.

\section{F. Literatur}

Berkhof, Louis. Teologi Sistematika 6: Doktrin Akhir Zaman. Surabaya: Momentum, 1997.

Boice, James Montgomery. Dasar-dasar Iman Kristen. Surabaya: Momentum, 2011.

Bruce, F. F. Ucapan Yesus Yang Sulit. Malang: Literatur SAAT, 2001.

Cole, R. Alan. The Tyndale New Testament Commentaries: Mark. Surabaya: Momentum, 2007.

Ferguson, Sinclair B., David F. Wright, J. I. Packer. New Dictionary of Theology Jilid 2. Malang: Literatur SAAT, 2009.

France, R. T. The Tyndale New Testament Commentaries: Matthew. Surabaya: Momentum, 2007.

Grudem, Wayne. Systematic Theology: An Introduction To Biblical Doctrine. Michigan: GrandRapids, 2000.

Hagner, Donald A.. Word Biblical Commentary: Matthew 1-13. Library of Congress Cataloging-in-Publication Data, 1993.

Hoekema, Anthony A.. Alkitab Dan Akhir Zaman. Surabaya: Momentum, 2004.

Osborne, Grant R. Exegetical Commentary on The New Testament. Michigan: Zondervan GrandRapids, 2010.

Ryrie, Charles C. Teologi Dasar 2. Yogyakarta: ANDI Offset, 1986.

Van Bruggen, Jacob. Markus: Injil Menurut Petrus. Jakarta: BPK Gunung Mulia, 2006. 